\section{WHO hospital care for children guidelines: what do users need?}

\author{
Trevor Duke $10,1,2$ Wilson Were ${ }^{3}$
}

In 2020, the World Health Organization is revising the Pocketbook of Hospital Care for Children, ${ }^{1}$ and we need your input. The Pocketbook of Hospital Care for Children contains guidelines for the management of common childhood illnesses. The target audience is nonspecialist or junior doctors or clinical officers, paediatric and general nurses and other healthcare workers who find themselves providing care for sick children in settings such as at district or provincial hospitals in low-income and middleincome countries. It is not a textbook of paediatrics, but an evidence-based practical clinical guideline. We want to know what you like about the book, where there are gaps, whether new diseases or conditions should be included, and whether any differences in formatting or structure or companion resources would make it easier to use. We seek your input on what, when and for whom a physical book is still useful, and for what needs it might be better to provide online content.

\section{HISTORY OF THE WHO POCKETBOOK OF HOSPITAL CARE FOR CHILDREN}

In 2005, the first edition of the Pocketbook of Hospital Care for Children was published. This followed a guideline book called Management of a Child with Serious Infection or Severe Malnutrition, published in 2000. The earlier book covered common infections in children plus malnutrition, and reflected the epidemiology of childhood illnesses in low-income and middle-income countries at the time. This first integrated guideline was well received, seen as an advance on separate guidelines such as for acute respiratory infection, diarrhoea, measles and malaria, and useful for the child health

${ }^{1}$ Intensive Care Unit and University of Melbourne Department of Paediatrics, Royal Children's Hospital, Parkville, Victoria, Australia

${ }^{2}$ Child Health, School of Medicine and Health Sciences, University of Papua New Guinea, Port Moresby, Papua New Guinea

${ }^{3}$ Maternal, Child and Adolescent Health, World Health Organization, Geneva, Switzerland

Correspondence to Professor Trevor Duke, Intensive Care Unit and University of Melbourne Department of Paediatrics, Royal Childrens Hospital, Parkville, VIC 3052, Australia; trevor.duke@rch.org.au worker who had to deal with the case-mix that presents to a district hospital. It was an extension of the Integrated Management of Childhood Illness (IMCI) to a hospital level. IMCI focused on primary care, ${ }^{2}$ but if hospitals of first referral had no guidelines and provided poor quality care, then IMCI would have limited effectiveness.

Health workers rightly pointed out that at a district hospital, they dealt with more than infections and malnutrition. And they needed to be able to carry a book around with them. Thus, the broader scope and pocket-size of the pocketbook of Hospital Care for Children. The book included other common conditions, such as asthma, seizures, surgical problems and importantly neonatal care. Health workers also pointed out that guidelines alone were not sufficient, and they needed training tools on how to use the guidelines in everyday clinical practice. A training course was developed on how to use the guidelines in everyday clinical practice, based on principles of adult learning. ${ }^{34}$ WHO developed the Emergency Triage, Assessment and Training (ETAT) course, focused on the first 24 hours of admission, and in Africa, ETAT + was a modified version which included admission care. ${ }^{5}$ Many quality improvement assessments and initiatives occurred, supported by WHO regional offices or initiated by countries. ${ }^{4}$

In 2013, the Pocketbook of Hospital Care for Children was revised, with updates in many areas. Many reviews were undertaken to identify new evidence for the revisions. An app was produced, and training materials updated. ${ }^{6}$ By 2015 , at least two-thirds of low-income and middle-income countries adopted the Hospital Care for Children guidelines, and ran training courses or other quality improvement initiatives. ${ }^{7}$

The Pocketbook of Hospital Care for Children has been used as the basis for paediatric curricula for medical students and nurses in many low-income and middle-income countries, and has been translated into at least 18 languages. ${ }^{3} \mathrm{~A}$ number of country and regional adaptations of the book have been achieved to reflect differences in disease epidemiology and local needs.

\section{THE FUTURE}

In 2020, what is needed of WHO Pocketbook of Hospital Care for Children? That is what we seek your input on. The epidemiology of child health has changed substantially in the last 20 years. More children are living with chronic conditions, there is a greater need to focus on quality of life and healthy development, and a recognition of the need for longterm care that extends from hospital to community. In the last 20 years, there has been an increased recognition of the importance of adolescent health, longterm care of high-risk newborns and a life-course approach. Antimicrobial resistance has markedly increased: and is a problem in the treatment of common bacterial infections in neonates and children, malaria, tuberculosis and HIV. This means effective treatments are more complex, often calling for 'second-line' guidance (such as clinical thresholds for changing antibiotics in common infections, and what second-line antibiotics to use). Many children need treatments that are individualised, based on tests that were previously unavailable (such as GeneXpert for multidrug-resistant TB, and CD4 counts and viral load testing for HIV). WHO Quality Standards for Care of Children have been published, and these call for more holistic paediatric services, and greater focus on family-centred care, and child-friendly services. ${ }^{8}$ And a pandemic of COVID-19 has disrupted so much in health services this year, so we need to keep balance, deal with the present, learn the lessons and look optimistically to the future. Such a book of clinical guidelines can drive change by setting standard, but it also has to be feasible in the context it will be used and remain relevant to the target audience.

Let us know how you think the WHO Pocketbook of Hospital Care for Children needs to be revised for the coming decade, as countries work to recovery after COVID-19 and to achieving the Sustainable Development Goals. Please email your suggestions with the subject heading: Feedback on Hospital Care for Children.

Contributors TD wrote the first draft, which was reviewed by WW.

Funding The authors have not declared a specific grant for this research from any funding agency in the public, commercial or not-for-profit sectors.

Competing interests None declared.

Patient consent for publication Not required.

Provenance and peer review Commissioned; externally peer reviewed.

(C) Author(s) (or their employer(s)) 2020. No commercial re-use. See rights and permissions. Published by BMJ. 


\section{Editorial}

\section{Check for updates}

To cite Duke T, Were W. Arch Dis Child 2020;105:711-712.

Published Online First 14 May 2020

Arch Dis Child 2020;105:711-712.

doi:10.1136/archdischild-2019-318752

ORCID iD

Trevor Duke http://orcid.org/0000-0003-4637-1416

\section{REFERENCES}

1 World Health Organization. Hospital care for children: guidelines for the management of common illnesses with limited resources. Geneva: WHO, ISBN 789241548373, 2013. Available: http://www.who.int/ maternal_child_adolescent/documents/child_hospital_ care/en/;

2 World Health Organization. IMCI chart booklet, 2013. Available: https://www.who.int/maternal_child_ adolescent/documents/IMCI_chartbooklet/en/ [Accessed Dec 2019].

3 MY L, Kelly J, Subhi R, et al. Global use of the WHO pocket book of hospital care for children. Paediatr Int Child Health 2013;33:4-11.

4 Campbell H, Duke T, Weber M, et al. Global initiatives for improving hospital care for children: state of the art and future prospects. Pediatrics 2008;121:e984-92.
5 Irimu G, Wamae A, Wasunna A, et al. Developing and introducing evidence based clinical practice guidelines for serious illness in Kenya. Arch Dis Child 2008;93:799-804.

6 World Health Organization. e-Pocket book of hospital care for children, 2016. Available: https://itunes. apple.com/us/app/who-e-pocketbook-hospital/ id 1044896085 ? ls=1 \&mt=8;

7 Li MY, Kelly J, Subhi R, et al. Global use of the WHO pocket book of hospital care for children. Paediatr Int Child Health 2013;33:4-17.

8 World Health Organization. Standards for improving the quality of care for children and young adolescents in health facilities. Geneva, 2018. 